\title{
Investigation of Borosilicate Glasses with Simulated HLW Components and Determination of Their Chemical Durability
}

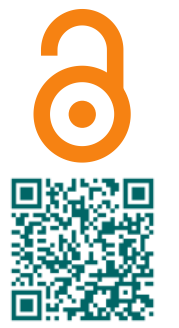

\author{
S.M. Shaydullin ${ }^{a b^{*}}$, E.A. Belanova ${ }^{\mathrm{b}}$, P.V. Kozlov ${ }^{\mathrm{bc}}$, M.B. Remizov $^{\mathrm{b}}$, \\ E.M. Dvoryanchikovab
}

a: Seversk Technological Institute - Branch of NRNU MEPhI (STI NRNU MEPhI), 636036, Kommunistichesky Av. 65, Seversk, Tomsk Region, Russia

b: FSUE Mayak Production Association, 456784, Lenin Str. 31, Ozyorsk, Chelyabinsk Region, Russia

c: Ozyorsk Technological Institute - Branch of NRNU MEPhI (OTI NRNU MEPhI), 456780, Pobeda Str. 48, Ozyorsk, Chelyabinsk Region, Russia

* Corresponding author: cpl@po-mayak.ru

This article belongs to the PCEE-2020 Special Issue.

(C) 2021, The Authors. This article is published in open access form under the terms and conditions of the Creative Commons Attribution (CC BY) license (http://creativecommons.org/licenses/by/4.o/).

\begin{abstract}
The paper discusses the current status of the HLW vitrification technology applied at the radiochemical plant of the Mayak PA. Conceptual and technical solutions proposed to develop the technology of vitrification of various types of liquid HLW at the Mayak PA are presented. Compositions of borosilicate glasses with HLW components are described, temperatures of their melting and easy pouring are determined. Chemical durability parameters obtained for the borosilicate glasses are provided.
\end{abstract}

\author{
Keywords \\ borosilicate glass \\ vitrification \\ high-level waste \\ chemical durability \\ vitrification melter \\ Received: 25.11.2020 \\ Revised: 02.03.2021 \\ Accepted: 03.03.2021 \\ Available online: 04.03.2021
}

\section{Introduction}

Isolation and safe storage of radioactive waste can by implemented by means of its immobilization with the use of durable, chemically resistant materials. While low-level and intermediate-level waste can be immobilized by means of cementation, solidification of high-level waste (HLW) requires more durable matrices, such as ceramics and glass. Glass is a nonstoichiometric compound that can dissolve, when heated, and then reliably confine, at subsequent cooling, a complex mixture of nuclear fuel fission products. The resulting isotropic, nonporous product is characterized by high chemical durability, radiation resistance and heat conductivity [1].

The objective of this work was to produce borosilicate glasses based on calcined simulated hydroxide sludge with a complex composition that simulated HLW accumulated in the storage tanks of the radiochemical plant and glass frit in various ratios, to determine the melting temperature, the temperature of easy pouring and chemical durability of the glasses. As a part of this study, the borosilicate glasses with a weight content of calcined solid ranging from 15 to $60 \%$ were produced and investigated. Acceptable chemical durability is demonstrated by the glass- es with a mass fraction of the calcined solid of no more than $30 \%$.

\section{Results and Discussion}

Two types of glasses are mainly applied for HLW immobilization; these include borosilicate and phosphate glasses [2]. As a rule, basic composition of borosilicate glass includes silicon, boron and sodium oxides, and aluminophosphate glass consists of aluminum, phosphorus and sodium oxides [3]. The glass composition is limited by solubility of individual HLW components in glass, on the one hand, and by the technological parameters of vitrification (waste denitration method, equipment applied for their calcination, heating method, solidification conditions, pouring from the melter, etc.), on the other hand.

Immobilization of the liquid HLW of the radiochemical plant in aluminophosphate glass has been carried out at the Mayak PA on the industrial scale since 1987. This method is implemented using nonremovable direct electric heating melters (EP-500). Over the past period of time, 4 such melters have reached the end of their design service life and have been decommissioned. Since December 27, 2016, the fifth industrial-scale electric furnace EP-500/5 designed for vitrification of liquid HLW has been in opera- 
tion. Its design service life is 6 years. The work is currently underway to develop the next melter of such type (EP250/6), the design of which will take into account the operational experience of the previous vitrification facilities, which is expected to prolong the service life of the new melter to approximately 8 years. Commissioning of this electric melter is scheduled for 2023.

Plans are underway at the Mayak PA to construct in 2028 a new vitrification complex that will enable solidifying a wide variety of liquid high-level waste. For example, small-size borosilicate glass melters with direct electrical heating are assumed to be used for solidification of liquid HLW generated as a result of reprocessing of SNF from power reactors (VVER-440, VVER-1000, BN-60o and BN800) [4]. The design-basis dismantling, disassembling and removing procedures are to be developed for these electric melters to ensure compliance with environmental regulations and to provide cost saving at construction of new facilities due to the use of considerable part of the infrastructure [5]. Solidification of other types of liquid HLW is planned to be implemented using EP melters, the design of which will provide for an inherent procedure of dismantling upon completion of the service life.

Thus, in the coming decade the main method for HLW solidification in Russia will still be based on radioactive waste vitrification in the direct electric heating melters. It is worth noting that the range of glasses applied for vitrification and characteristics of waste to be solidified will be expanded [6].

In compliance with the IAEA standards, liquid HLW is subject to solidification [7]. The main objective is to reduce the HLW volume as much as possible and to provide the HLW conditioning, i.e. conversion of the radioactive waste into chemically durable and radiation-resistant form that maintains its stability throughout the entire storage period. From the point of view of long-term environmental safety, chemical durability is of paramount importance.

In spite of the fact that borosilicate glass has long been used abroad for radioactive waste solidification, systematic investigations of physical and chemical properties of this type of glass have been carried out in Russia mainly during the recent 20 years.
The objective of this work was to produce borosilicate glasses based on calcined simulated hydroxide sludge with a complex composition that simulated HLW accumulated in the storage tanks of the radiochemical plant and glass frit in various ratios, to determine the melting temperature, the temperature of easy pouring and chemical durability of the glasses.

Compositions of the investigated borosilicate glasses and the initial glass frit, melting temperatures and easy pouring temperatures are provided in Table 1 . These compositions were selected based on the variety of HLW vitrified into borosilicate glass.

Calcined solid is a product resulting from reprocessing of simulated hydroxide sludge from one of the storage tanks. The storage tanks are fourteen concrete compartments, $1170 \mathrm{~m}^{3}$ each, isolated from each other and lined with stainless steel of $12 \mathrm{X} 18 \mathrm{H} 9 \mathrm{~T}$ grade with a thickness of $3 \mathrm{~mm}$. The storage tanks were actively filled with heterogeneous high-level waste (HLW) between 1968 and 1986. The storage tanks are located on the ground surface, which excludes the possibility of ground water ponding [8]. The storage tanks contain slightly alkaline and alkaline systems of precipitates, suspensions and clarified solutions. The precipitates mainly contain iron, aluminum, nickel and chromium hydroxides, iron and nickel sulfides, nickel-cesium and titanium-cesium ferrocyanides. The liquid phase contains high salinity solutions, chemical composition of which is determined mainly by sodium hydroxide, aluminate and nitrate. Radionuclide composition is represented mainly by fission products and is different for the clarified phase and the precipitate. The liquid phase activity is conditioned mainly by cesium-137; the precipitate also contains considerable amount of strontium-9o (in equilibrium with yttrium-90), as well as fissionable components such as uranium and plutonium.

The sludge composition is provided in Table 2.

As it is a challenging task to synthesize sludge of such composition under laboratory conditions, its ninefold dilution was assumed by convention. Consequently, aluminum, iron, chromium, nickel, manganese, magnesium and calcium hydroxides were produced directly by precipitation of the elements from the nitric acid solution using sodium hydroxide.

Table 1 Compositions of the investigated glasses, melting temperatures and easy pouring temperatures

\begin{tabular}{|c|c|c|c|c|c|c|c|c|c|c|c|c|c|c|c|}
\hline \multirow{2}{*}{$\begin{array}{l}0 \\
z \\
0 \\
0 \\
\pi \\
0\end{array}$} & \multicolumn{13}{|c|}{ Mass fraction of oxides in borosilicate glasses, $\%$} & \multirow[b]{2}{*}{$T_{\mathrm{m} .},{ }^{\circ} \mathrm{C}$} & \multirow[b]{2}{*}{$T_{\text {e.p. }}{ }^{\circ} \mathrm{C}$} \\
\hline & $\mathrm{SiO}_{2}$ & $\mathrm{~B}_{2} \mathrm{O}_{3}$ & $\mathrm{Li}_{2} \mathrm{O}$ & $\mathrm{Na}_{2} \mathrm{O}$ & $\mathrm{Al}_{2} \mathrm{O}_{3}$ & $\mathrm{Fe}_{2} \mathrm{O}_{3}$ & $\mathrm{Cr}_{2} \mathrm{O}_{3}$ & $\mathrm{NiO}$ & $\mathrm{MnO}$ & $\mathrm{CaO}$ & $\mathrm{K}_{2} \mathrm{O}$ & $\mathrm{MgO}$ & $\mathrm{SO}_{3}$ & & \\
\hline $\begin{array}{l}\text { Glass } \\
\text { frit }\end{array}$ & 72.00 & 8.00 & 8.00 & 12.00 & - & - & - & - & - & - & - & - & - & - & 1200 \\
\hline 1 & 61.43 & 6.80 & 6.80 & 18.69 & 3.19 & 0.56 & 0.26 & 0.67 & 0.18 & 0.09 & 0.67 & 0.13 & 0.54 & 1050 & 1150 \\
\hline 2 & 50.85 & 5.60 & 5.60 & $25 \cdot 37$ & 6.37 & 1.13 & 0.52 & 1.33 & 0.36 & 0.19 & 1.34 & 0.26 & 1.07 & 1000 & 1100 \\
\hline 3 & 40.28 & 4.40 & 4.40 & 32.06 & $9 \cdot 56$ & 1.69 & 0.77 & 2.00 & 0.55 & 0.28 & 2.01 & 0.39 & 1.61 & 950 & 1000 \\
\hline 4 & 29.71 & 3.20 & 3.20 & 38.75 & 12.74 & 2.26 & 1.03 & 2.66 & 0.73 & 0.37 & 2.69 & 0.52 & 2.14 & 900 & 950 \\
\hline
\end{tabular}


Table 2 Content of components in the hydroxide sludge on condition that the precipitate and the liquid phase are homogenized

\begin{tabular}{|c|c|c|}
\hline Component & $\begin{array}{l}\text { Concentration of components in the real } \\
\text { sludge, g/L }\end{array}$ & $\begin{array}{l}\text { Concentration of components in the ninefold } \\
\text { diluted sludge, } \mathrm{g} / \mathrm{L}\end{array}$ \\
\hline $\mathrm{Na}$ & 170.3 & 18.9 \\
\hline $\mathrm{Al}$ & 181.5 & 20.2 \\
\hline $\mathrm{Fe}$ & 42.5 & $4 \cdot 7$ \\
\hline $\mathrm{Cr}$ & 19.1 & 2.1 \\
\hline $\mathrm{Ni}$ & 56.3 & 6.3 \\
\hline Mn & 15.0 & 1.7 \\
\hline $\mathrm{Mg}$ & 8.4 & 0.9 \\
\hline $\mathrm{Ca}$ & $7 \cdot 3$ & 0.8 \\
\hline $\mathrm{K}$ & 60.0 & 6.7 \\
\hline $\mathrm{SO}_{4}{ }^{2-}$ & 69.1 & $7 \cdot 7$ \\
\hline $\mathrm{Cl}^{-}$ & 0.37 & 0.04 \\
\hline $\mathrm{NO}_{3}^{-}$ & 30.7 & 3.4 \\
\hline
\end{tabular}

The sodium hydroxide solution with a concentration of $500 \mathrm{~g} / \mathrm{L}$ was added to the nitric acid solution so that hydroxides of the above-mentioned elements precipitated completely; as a consequence, the simulated laboratory sludge turned out to have higher sodium content. Potassium was introduced in the form of potassium nitrate, sulfate-ions in the form of sodium sulfate, chloride-ions in the form of sodium chloride and silicon in the form of colloidal silicon oxide (aerosil). Upon completion of the precipitation, a system consisting of a solid and a liquid phase was obtained. The solid phase contained aluminum, iron, chromium, nickel, manganese, magnesium, calcium and silicon. The liquid phase was formed by potassium, sodium, nitrate-, chloride- and sulfate-ions.

In the course of the investigations the sludge was evaporated to dry residue and thermally treated at $600{ }^{\circ} \mathrm{C}$ for 2 hours. To ensure more complete calcination, the sludge was additionally held for 2 hours at $800{ }^{\circ} \mathrm{C}$.

The final composition of the simulated hydroxide sludge produced under laboratory conditions and the related calcined solid composition are provided in Table 3 . The data were obtained using an inductively coupled plasma mass spectrometer.
Glass of four compositions was produced based on the calcined simulated hydroxide sludge with a complex composition and the glass frit in various ratios:

- calcined solid - 15\%, frit - 85\%;

- calcined solid - 30\%, frit - 70\%;

- calcined solid - $45 \%$, frit - 55\%;

- calcined solid - 60\%, frit - 40\%.

The glass-forming calcined solid was melted at a temperature ranging from $800{ }^{\circ} \mathrm{C}$ to $1050{ }^{\circ} \mathrm{C}$. As each glass composition is characterized by its individual melting temperature, the condition of the crucible contents was visually examined at intervals of $50{ }^{\circ} \mathrm{C}$ (starting from $800{ }^{\circ} \mathrm{C}$ ). The glass melting temperature was recorded at the moment of the calcined solid conversion into melt. In order to reach complete homogenization of the melt, it was held at the abovementioned temperature for 2 hours. Then the heating was continued at intervals of $50{ }^{\circ} \mathrm{C}$ to determine the temperature of easy pouring of the melt, which was assessed visually judging by the melt fluidity. Quenched glass was produced by rapid cooling of the melt to room temperature at its discharge on the metal plate made of stainless steel.

Table 3 The composition of the hydroxide sludge produced under laboratory conditions and the corresponding calcined solid composition

\begin{tabular}{|c|c|c|c|c|c|}
\hline $\begin{array}{c}\text { Components of simu- } \\
\text { lated hydroxide } \\
\text { sludge }\end{array}$ & $\begin{array}{l}\text { Component concentra- } \\
\text { tion in the sludge, } \mathrm{g} / \mathrm{L}\end{array}$ & $\begin{array}{l}\text { Complete composi- } \\
\text { tion of the simulated } \\
\text { hydroxide sludge }\end{array}$ & $\begin{array}{l}\text { Component concen- } \\
\text { tration in the sludge, } \\
\mathrm{g} / \mathrm{L}\end{array}$ & $\begin{array}{l}\text { Complete composition } \\
\text { of the calcined simulat- } \\
\text { ed hydroxide sludge }\end{array}$ & $\begin{array}{l}\text { Mass fraction of } \\
\text { oxides in the } \\
\text { calcined solid, \% }\end{array}$ \\
\hline $\mathrm{Al}$ & 19.64 & $\mathrm{Al}(\mathrm{OH})_{3}$ & 56.76 & $\mathrm{Al}_{2} \mathrm{O}_{3}$ & 21.24 \\
\hline $\mathrm{Fe}$ & 4.60 & $\mathrm{Fe}(\mathrm{OH})_{3}$ & 8.82 & $\mathrm{Fe}_{2} \mathrm{O}_{3}$ & 3.76 \\
\hline $\mathrm{Cr}$ & 2.07 & $\mathrm{Cr}(\mathrm{OH})_{3}$ & 4.09 & $\mathrm{Cr}_{2} \mathrm{O}_{3}$ & 1.72 \\
\hline $\mathrm{Ni}$ & 6.09 & $\mathrm{Ni}(\mathrm{OH})_{2}$ & 9.61 & $\mathrm{NiO}$ & $4 \cdot 44$ \\
\hline Mn & 1.62 & $\mathrm{Mn}(\mathrm{OH})_{2}$ & 2.64 & $\mathrm{MnO}$ & 1.21 \\
\hline $\mathrm{Mg}$ & 0.91 & $\mathrm{Mg}(\mathrm{OH})_{2}$ & 2.18 & MgO & 0.87 \\
\hline $\mathrm{Ca}$ & 0.79 & $\mathrm{Ca}(\mathrm{OH})_{2}$ & 1.45 & $\mathrm{CaO}$ & 0.62 \\
\hline $\mathrm{K}$ & 6.49 & $\mathrm{KOH}$ & $5 \cdot 52$ & $\mathrm{~K}_{2} \mathrm{O}$ & $4 \cdot 48$ \\
\hline $\mathrm{Na}$ & 73.28 & $\mathrm{KNO}_{3}$ & 6.82 & $\mathrm{Na}_{2} \mathrm{O}$ & 53.78 \\
\hline $\mathrm{Si}$ & 1.23 & $\mathrm{NaNO}_{3}$ & 257.58 & $\mathrm{SiO}_{2}$ & 1.51 \\
\hline $\mathrm{SO}_{4}{ }^{2-}$ & 7.48 & $\mathrm{SiO}_{2}$ & 2.64 & $\mathrm{SO}_{3}$ & $3 \cdot 57$ \\
\hline $\mathrm{Cl}^{-}$ & 0.04 & $\mathrm{Na}_{2} \mathrm{SO}_{4}$ & 11.06 & $\mathrm{NaCl}$ & 0.03 \\
\hline $\mathrm{NO}_{3}^{-}$ & 187.9 & $\mathrm{NaCl}$ & 0.06 & & \\
\hline
\end{tabular}


It was established that the glass melting temperature ranged from $900{ }^{\circ} \mathrm{C}$ to $1050{ }^{\circ} \mathrm{C}$ and the easy pouring temperature was from $950^{\circ} \mathrm{C}$ to $1150^{\circ} \mathrm{C}$ (see Table 1), which is fully consistent with the temperature mode of operation of the vitrification furnaces designed at the Mayak PA. The produced glass was homogenous and transparent throughout its entire volume.

The glasses with compositions 1 to 4 were tested for chemical durability. To test the glasses according to the procedure described in State Standard GOST R 52126 [9], glass fractions with a particle size ranging from 0.16 to $0.25 \mathrm{~mm}$ were prepared. Specific surface area of the powder was $120 \mathrm{~cm}^{2} / \mathrm{g}$. Before the testing, the glass powders were washed with ethyl alcohol to remove dust fraction and dried.

According to a method of long-term leaching, weighed powder samples with a weight of $0.3 \mathrm{~g}$ with a total surface area of $36 \mathrm{~cm}^{2}$ were placed into polyethylene containers with sealed lids, where $50 \mathrm{~cm}^{3}$ of deionized water was added. The samples were held at a temperature of $(23 \pm 2)$ ${ }^{\circ} \mathrm{C}$. The contact solution was replaced in 1, 3, 7, 10, 14, 21, 28, 35, 56 and 91 days after the testing was started.

At the end of the specified period of time, the contact solution was decanted and analyzed to determine the element content using inductively coupled plasma massspectrometry (ICP-MS).
According to Rules and Regulations NP-019-2015 [10], chemical durability of phosphate glasses is evaluated based on cesium-137 leaching, the standard leaching rate of which must not exceed $1 \cdot 10^{-5} \mathrm{~g} /\left(\mathrm{cm}^{2} \cdot\right.$ day $)$. In the framework of this research, chemical durability of the borosilicate glasses was determined based on the leaching rate of lithium, sodium and potassium that are chemical analogs of cesium. Among the above-mentioned univalent elements, lithium and sodium are the most mobile elements due to their small ionic radius. Besides, leaching of matrix components (silicon and boron) and HLW components (aluminum) was investigated to assess behavior of multivalent elements.

The degree of element leaching is an additional criterion for evaluation of the chemical durability of the glass. This value is not normalized; however, it provides a more accurate estimate of the matrix quality.

The rate of the element leaching from the matrix determined using the long-term leaching method is a differential quantity, while the leaching degree is an integral quantity.

The results of the element leaching from the borosilicate glasses with compositions 1 to 4 , produced using the long-term leaching method for 1, 3, 7, 10, 14, 21, 28, 35, 56 and 91 days from the beginning of the experiment, are provided in Figs. 1 to 6 and in Table 4.

Table 4 Summarized data on leaching of elements from quenched borosilicate glasses obtained using the long-term leaching method

\begin{tabular}{|c|c|c|c|c|}
\hline \multirow{2}{*}{ Glass number } & \multicolumn{2}{|c|}{ Differential leaching rate, $\mathrm{g} /\left(\mathrm{cm}^{2} \cdot\right.$ day $)$} & \multicolumn{2}{|c|}{ Leaching degree, $\%$} \\
\hline & On the $1^{\text {st }}$ day & On the $91^{\text {st }}$ day & Over 1 day & Over 91 days \\
\hline \multicolumn{5}{|c|}{ Lithium } \\
\hline 1 & $1.48 \cdot 10^{-5}$ & $3 \cdot 74 \cdot 10^{-7}$ & 0.18 & 1.12 \\
\hline 2 & $2.12 \cdot 10^{-5}$ & $1.69 \cdot 10^{-6}$ & 0.25 & 2.68 \\
\hline 3 & $4.23 \cdot 10^{-5}$ & $4.69 \cdot 10^{-6}$ & 0.51 & 9.19 \\
\hline 4 & $1.78 \cdot 10^{-4}$ & $1.01 \cdot 10^{-5}$ & 2.14 & 21.34 \\
\hline \multicolumn{5}{|c|}{ Sodium } \\
\hline 1 & $8.34 \cdot 10^{-6}$ & $5.40 \cdot 10^{-7}$ & 0.10 & 0.99 \\
\hline 2 & $8.22 \cdot 10^{-6}$ & $2.11 \cdot 10^{-6}$ & 0.10 & 1.85 \\
\hline 3 & $1.69 \cdot 10^{-5}$ & $5.21 \cdot 10^{-6}$ & 0.20 & $5 \cdot 54$ \\
\hline 4 & $5 \cdot 36 \cdot 10^{-5}$ & $1.00 \cdot 10^{-5}$ & 0.64 & 13.12 \\
\hline \multicolumn{5}{|c|}{ Potassium } \\
\hline 1 & $4.63 \cdot 10^{-6}$ & $4 \cdot 73 \cdot 10^{-7}$ & 0.06 & 0.91 \\
\hline 2 & $8.10 \cdot 10^{-6}$ & $8.25 \cdot 10^{-7}$ & 0.10 & 1.35 \\
\hline 3 & $1.10 \cdot 10^{-5}$ & $2.11 \cdot 10^{-6}$ & 0.13 & 2.31 \\
\hline 4 & $4.65 \cdot 10^{-5}$ & $3.88 \cdot 10^{-6}$ & 0.56 & 6.39 \\
\hline \multicolumn{5}{|c|}{ Boron } \\
\hline 1 & $7.42 \cdot 10^{-6}$ & $5 \cdot 35 \cdot 10^{-7}$ & 0.09 & 1.13 \\
\hline 2 & $6.13 \cdot 10^{-6}$ & $2.68 \cdot 10^{-6}$ & 0.07 & 2.83 \\
\hline 3 & $2.65 \cdot 10^{-5}$ & $7.18 \cdot 10^{-6}$ & 0.32 & $9 \cdot 52$ \\
\hline 4 & $6.95 \cdot 10^{-5}$ & $1.43 \cdot 10^{-5}$ & 0.83 & 23.08 \\
\hline \multicolumn{5}{|c|}{ Silicon } \\
\hline 1 & $2.54 \cdot 10^{-7}$ & $1.41 \cdot 10^{-8}$ & 0.003 & 0.035 \\
\hline 2 & $2.72 \cdot 10^{-7}$ & $3.41 \cdot 10^{-8}$ & 0.003 & 0.051 \\
\hline 3 & $2.58 \cdot 10^{-6}$ & $1.57 \cdot 10^{-6}$ & 0.03 & 2.02 \\
\hline 4 & $8.26 \cdot 10^{-6}$ & $1.82 \cdot 10^{-6}$ & 0.10 & 4.60 \\
\hline \multicolumn{5}{|c|}{ Aluminum } \\
\hline 1 & $1.13 \cdot 10^{-6}$ & $4 \cdot 54 \cdot 10^{-9}$ & 0.014 & 0.067 \\
\hline 2 & $8.69 \cdot 10^{-7}$ & $1.78 \cdot 10^{-8}$ & 0.010 & 0.044 \\
\hline 3 & $2.08 \cdot 10^{-6}$ & $1.92 \cdot 10^{-7}$ & 0.03 & 0.35 \\
\hline 4 & $3.77 \cdot 10^{-6}$ & $4.87 \cdot 10^{-7}$ & 0.05 & 1.87 \\
\hline
\end{tabular}




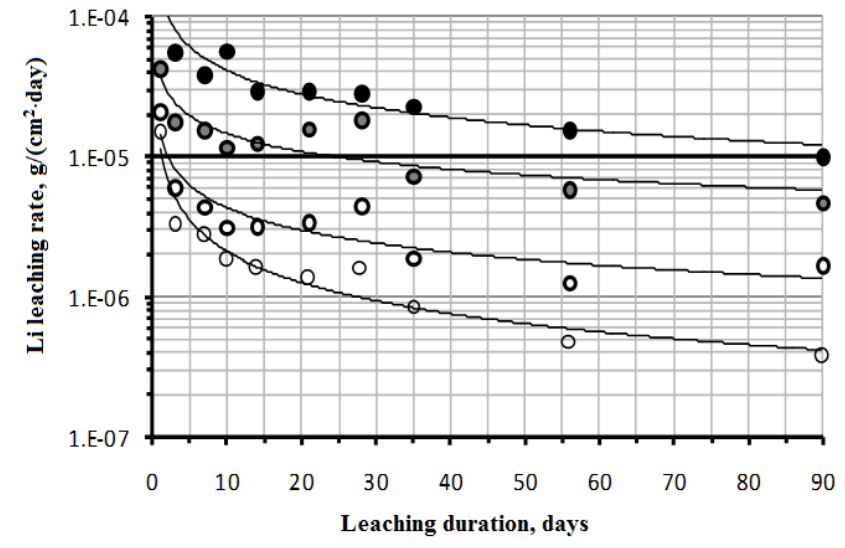

O Glass composition No 10 Glass composition No 2

- Glass composition No 3 Glass composition No 4

(a)

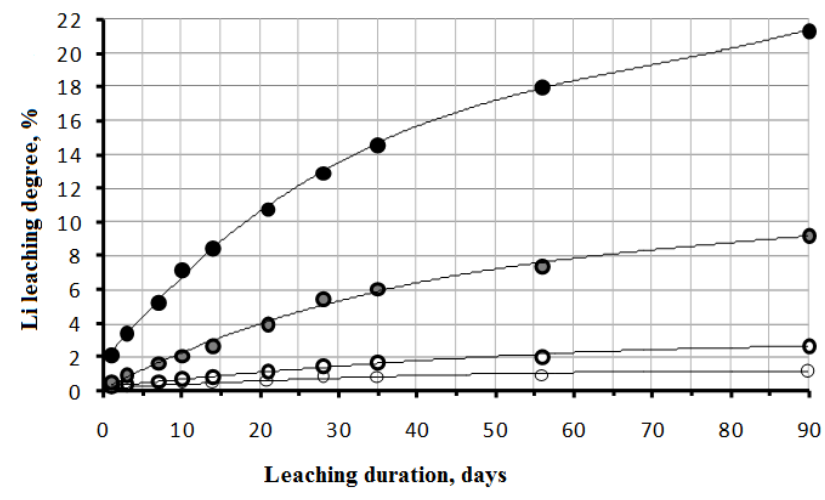

O Glass composition No 1 O Glass composition No 2

- Glass composition No 3 Glass composition No 4

(b)

Fig. 1 Rate (a) and degree (b) of lithium leaching from the quenched borosilicate glasses with compositions 1 to 4 versus the duration of leaching

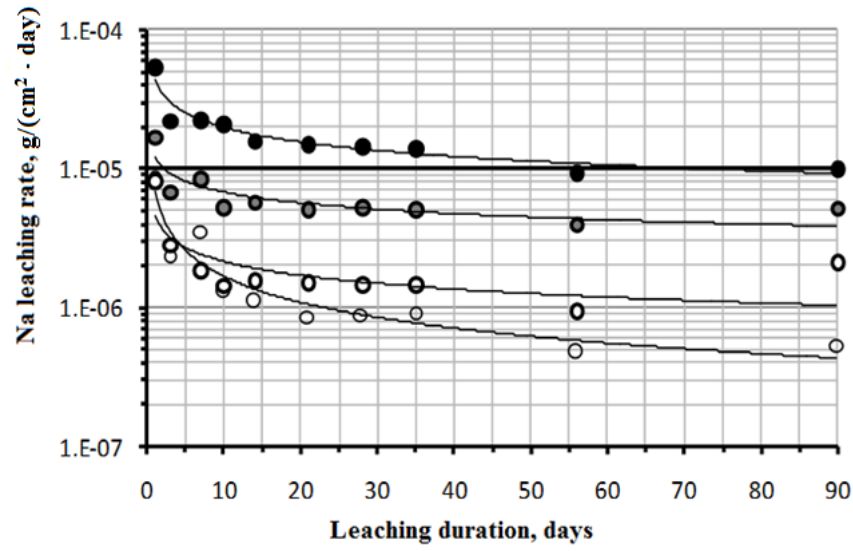

OGlass composition No 10 Glass composition No 2

- Glass composition No 3 Glass composition No 4

(a)

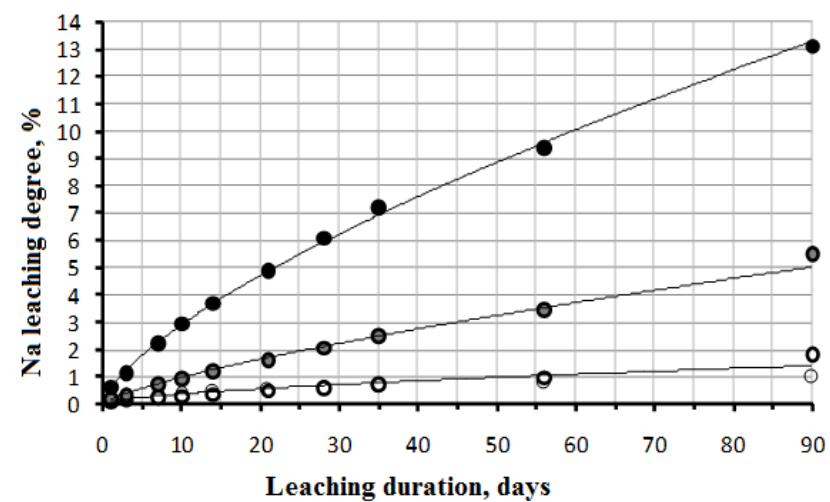

- Glass composition No 1 o Glass composition No 2

- Glass composition No $3 \bullet$ Glass composition No 4

Fig. 2 Rate (a) and degree (b) of sodium leaching from the quenched borosilicate glasses with compositions 1 to 4 versus the duration of leaching

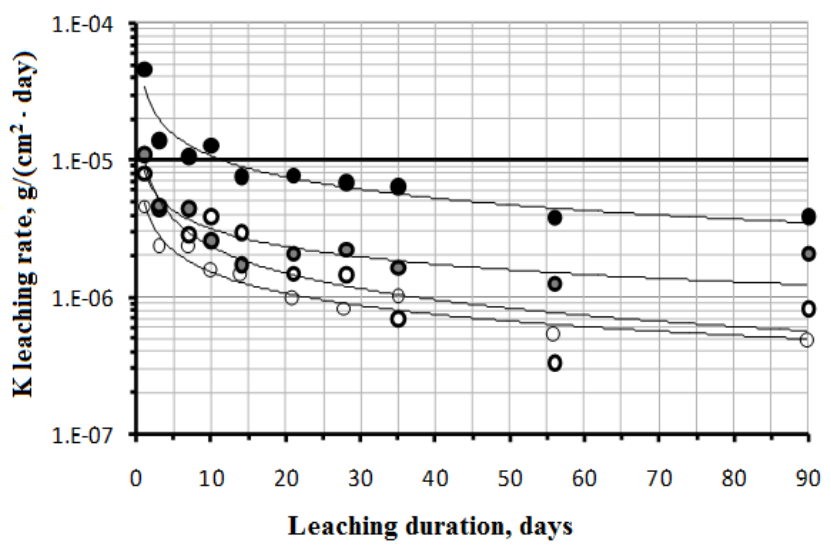

OGlass composition No 1 o Glass composition No 2

-Glass composition No $3 \bullet$ Glass composition No 4

(a)

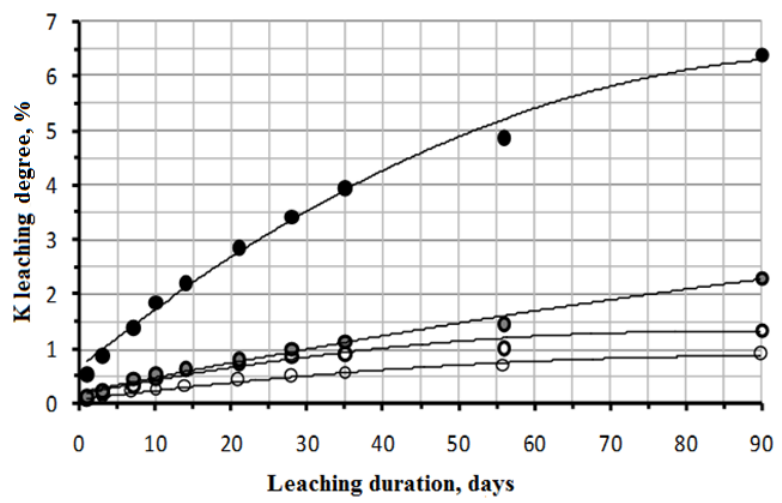

O Glass composition No 1 Glass composition No 2

- Glass composition No 3 Glass composition No 4

Fig. 3 Rate (a) and degree (b) of potassium leaching from the quenched borosilicate glasses with compositions 1 to 4 versus the duration of leaching 


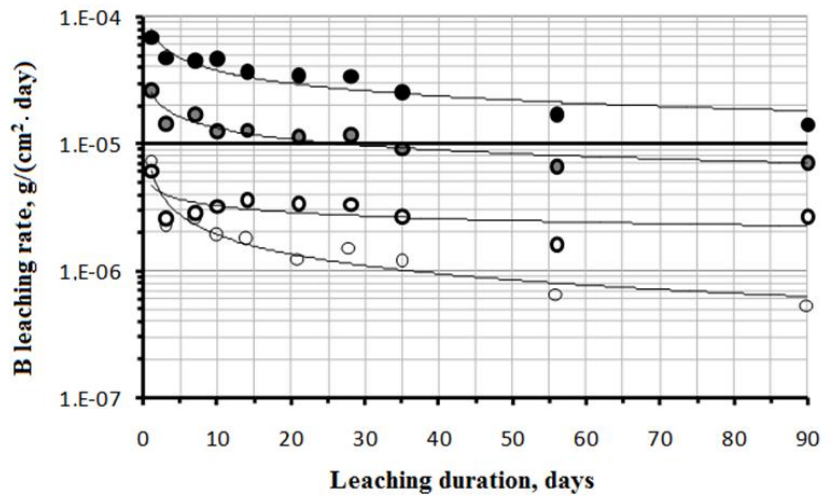

○ Glass composition No 1 - Glass composition No 2

- Glass composition No 3 Glass composition No 4

(a)

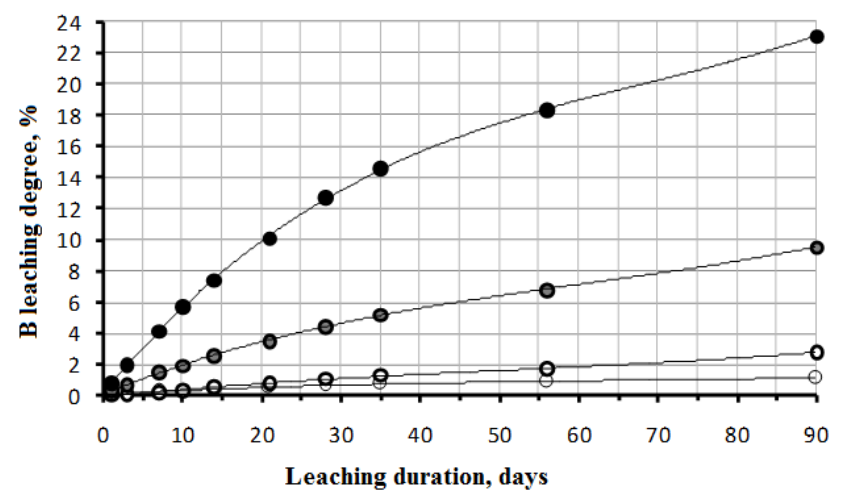

O Glass composition No 1 Glass composition No 2

- Glass composition No 3 Glass composition No 4

(b)

Fig. 4 Rate (a) and degree (b) of boron leaching from the quenched borosilicate glasses with compositions 1 to 4 versus the duration of leaching

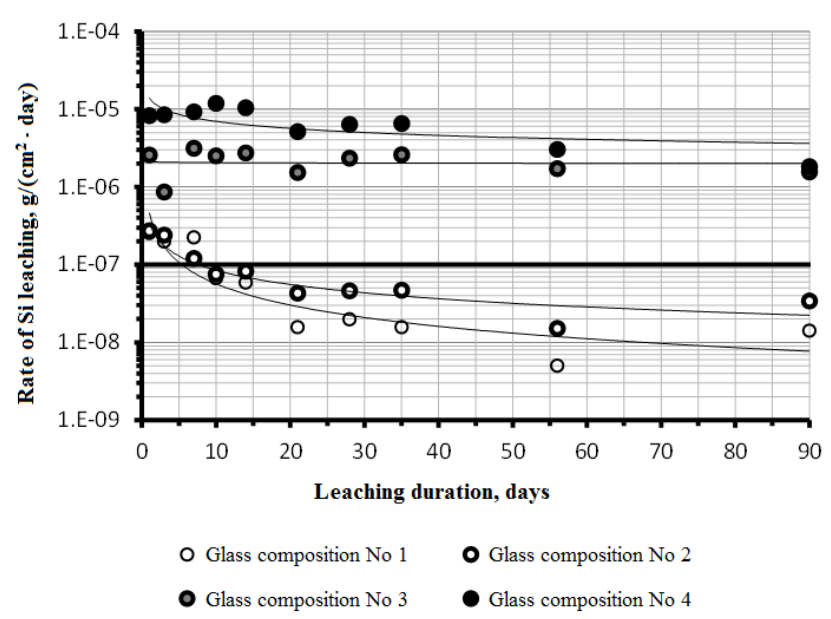

(a)

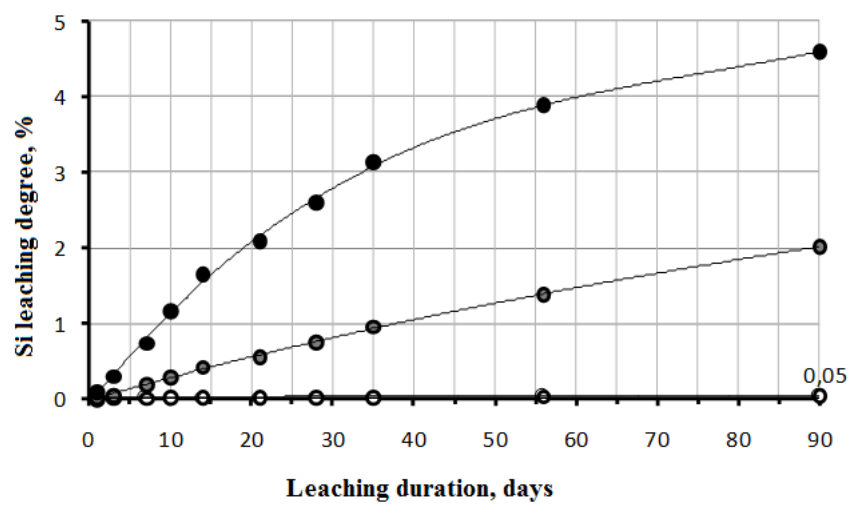

○ Glass composition No 1 G Glass composition No 2

- Glass composition No 3 - Glass composition No 4

(b)

Fig. 5 Rate (a) and degree (b) of silicon leaching from the quenched borosilicate glasses with compositions 1 to 4 versus the duration of leaching

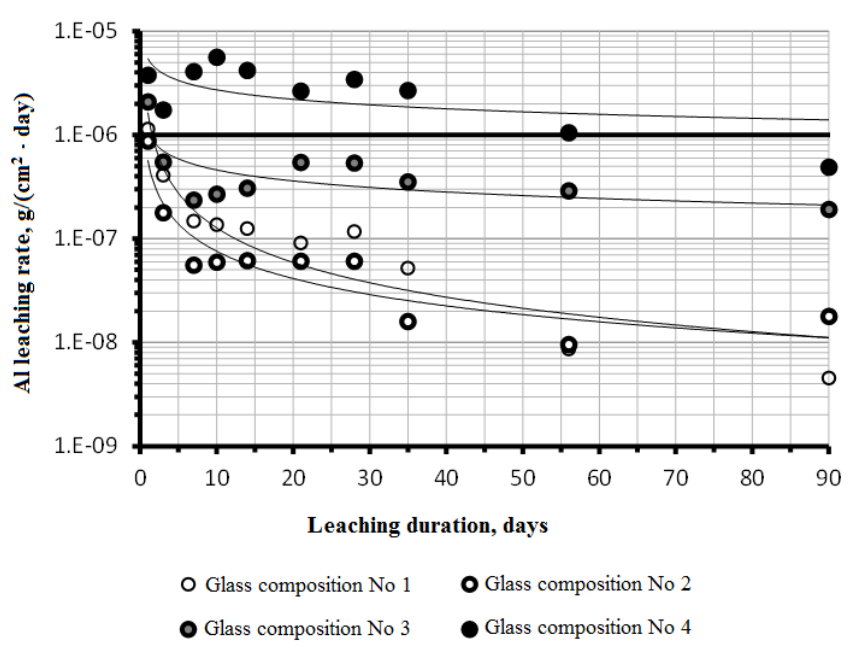

(a)

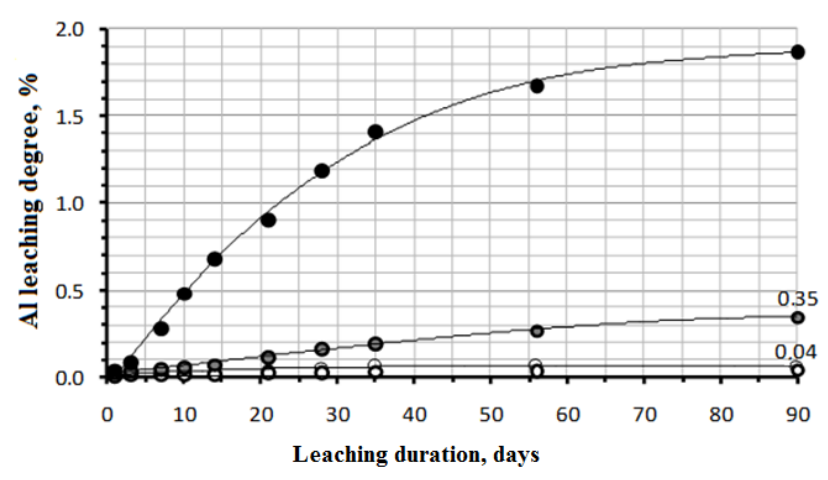

○ Glass composition No $1 \bigcirc$ Glass composition No 2

- Glass composition No $3 \bullet$ Glass composition No 4

(b)

Fig. 6 Rate (a) and degree (b) of aluminum leaching from the quenched borosilicate glasses with compositions 1 to 4 versus the duration of leaching

As can be seen from the data provided in Table 4 , the chemical durability of the borosilicate glasses (from composition 1 to composition 4) decreases with an increase in the mass fraction of the calcined sludge (from 15 to $60 \%$ ) in them. This phenomenon is associated with growth in sodium oxide concentration in the glass (due to the high 
sodium content in the simulated hydroxide sludge) and with the decrease in concentration of other important components contained in the frit that form threedimensional framework of the glass material (silicon and boron oxides).

The glasses with compositions 1 and 2 are characterized with maximum chemical durability. Sodium and potassium leaching rates had already been below the standard level of $\left(1 \cdot 10^{-5} \mathrm{~g} /\left(\mathrm{cm}^{2}\right.\right.$.day $\left.)\right)$ at the beginning of the testing, and the leaching rate of lithium reached the specified reference level at the end of the $3^{\text {rd }}$ day. It is worth noting that the leaching degree of the three elements over the entire testing period of 91 days did not exceed $3 \%$ [10].

It was noted that boron behavior at leaching was identical to that of sodium.

As for silicon, it has the lowest leaching indices; and in compliance with Rules and Regulations NP-019-2015 [10] they are comparable with a standard leaching rate of $\left(1 \cdot 10^{-7} \mathrm{~g} /\left(\mathrm{cm}^{2} \cdot\right.\right.$ day $\left.)\right)$ for plutonium. Such a level is reached at the end of the $7^{\text {th }}$ day, and the leaching degree for the entire testing period is not more than $0.051 \%$.

Average initial rate of aluminum leaching from the glasses with compositions 1 and 2 is $1 \cdot 10^{-6} \mathrm{~g} /\left(\mathrm{cm}^{2} \cdot\right.$ day $)$, which is comparable with the standard leaching rate of strontium. Besides, the degree of aluminum leaching over 91 days does not exceed $0.1 \%$.

An increase in the mass fraction of alkaline elements in glasses (compositions 3 and 4 ) causes an increase in their content in the leachate, which, in its turn, speeds up the dissolution of the silicon oxide.

\section{Conclusions}

As a part of this study, the borosilicate glasses with a weight content of calcined solid ranging from 15 to $60 \%$ were produced and investigated. The calcined solid contained the components of the hydroxide sludge with a complex composition that simulated HLW of the radiochemical plant. The melting temperature of the glasses ranges from $900{ }^{\circ} \mathrm{C}$ to $1050^{\circ} \mathrm{C}$, and the easy pouring temperature is in the range from $950^{\circ} \mathrm{C}$ to $1150{ }^{\circ} \mathrm{C}$, which is fully consistent with the temperature mode of operation of the vitrification furnaces designed at the Mayak PA.

The glasses with compositions 1 and 2 are characterized with maximum chemical durability. Sodium and potassium leaching rates had already been below the standard level of $\left(1 \cdot 10^{-5} \mathrm{~g} /\left(\mathrm{cm}^{2}\right.\right.$.day $\left.)\right)$ at the beginning of the testing, and the leaching rate of lithium reached the specified reference level at the end of the $3^{\text {rd }}$ day. It was noted that boron behavior at leaching was identical to that of sodium. As for silicon, it has the lowest leaching indices; they are comparable with a standard leaching rate of $\left(1 \cdot 10^{-7} \mathrm{~g} /\left(\mathrm{cm}^{2} \cdot\right.\right.$ day $\left.)\right)$ for plutonium.
Acceptable chemical durability is demonstrated by the glasses with a mass fraction of the calcined solid of no more than $30 \%$.

\section{References}

1. Goel A, McCloy JS, Pokorny R, Kruger AA. Challenges with vitrification of Hanford High-Level Waste (HLW) to borosilicate glass - An overview. J Non-Cryst Solids: X. 2019;4:100033. doi:10.1016/j.nocx.2019.100033

2. Ozhovan MI, Poluektov PP. Primeneniye styokol pri immobilizatsii radioaktivnykh otkhodov [The use of glass for immobilization of radioactive waste]. Bezopasnost' okruzhayushchey sredy [Environmental Safety]. 2010;1:112-5. Russian.

3. Vedishcheva NM, Shakhmatkin BA, Wright AC. The structure of sodium borosilicate glasses: thermodynamic modeling vs. experiment. J Non-Cryst Solids. 2004;345-6;39-44. doi:10.1016/j.jnoncrysol.2004.07.040

4. Kozlov PV, Remizov MB, Belanova EA, Vlasova NV, Orlova VA, Martynov KV. Modifikatsiya sostava alyumofosfatnykh styokol s imitatorami VAO dlya povysheniya ikh ustoychivosti. 1. Vliyaniye modifikatorov na vyazkost' i kristallizatsionnuyu sposobnost' rasplavov [Modification of composition of aluminophosphate glasses with simulated HLW to increase their durability. 1. Effect of modifiers on viscosity and crystallization capacity of melts]. Voprosy radiatsyonnoy bezopasnosti [Radiation Safety Problems]. 2019;1:3-15. Russian.

5. Shaydullin SM, Kozlov PV, Remizov MB, Verbitsky KV, Melentyev AB, Bendasov DI. Plavitel' s donnym slivom dlya otverzhdeniya VAO v borosilikatnoye steklo. Aktual'nye problemy innovatsionnogo razvitiya yadernykh tekhnologiy [Melter with bottom drain for HLW immobilization in borosilicate glass. Topical issues of innovative development of nuclear technologies]: In: Abstracts of the conference in the framework of scientific session at NRNU MEPhI; 2019 April 8-12; Seversk, Russia. p. 4 Russian.

6. Batorshin GSh, Remizov MB, Kozlov PV, Logunov MV, Kustov SV. Tekhnologiya pererabotki yadernogo naslediya FGUP PO Mayak - nakoplennykh vysokoaktivnykh geterogennykh otkhodov [Technology for Reprocessing of Nuclear Legacy High-Level Heterogeneous Waste Accumulated at the Mayak PA]. Voprosy radiatsyonnoy bezopasnosti [Radiation Safety Problems]. 2015;1:3-10. Russian.

7. Underground Disposal of Radioactive Waste. General Guidelines. IAEA Safety Series No. 54. Vienna: IAEA, 1981. 56 p.

8. Kozlov PV, Remizov MB, Makarovsky RA, Dementyeva II, Lupekha NA, Zubrilovsky EN, Kustov SV, Miroshnichenko AA. Osnovnye podkhody, opyt i problem pererabotki nakoplennykh v yomkostyakh zhidkikh radioaktivnykh otkhodov slozhnogo himicheskogo sostava [Main Approaches, Practices and Problems of Reprocessing of Radioactive Waste with Complex Chemical Composition Accumulated in the Storage Tanks]. Radioaktivnye otkhody [Radioactive Waste]. 2018[cited 2020 November 25];4(5):55-64. Russian. Available from:

http://ibrae.ac.ru/docs/Radwaste Journal 4(5)18/055066 Kozlov BASIC $\% 20 A P P R O A C H E S, \% 20$ EXPERIENCE $\% 20$ AND\%20PROBLEMS.pdf

9. Radioactive Waste. Opredeleniye khimicheskoy ustoychivosti otverzhdyonnnykh vysokoaktivnykh otkhodov metodom dlitelnogo vyshchelachivaniya. GOST R 52126-2003 [Determination of Chemical Stability of Solidified High-Level Waste Using Long-Term Leaching Method. State Standard GOST R 52126-2003]. Moscow: IPK Standards Publishing House, 2003. 5 p. Russian.

10. Sbor, pererabotka, khranenye i konditsionirovaniye zhidkikh radioaktivnykh otkhodov. Trebovaniya bezopasnosti. NP-0192015 [Collection, Reprocessing, Storage and Conditioning of Liquid Radioactive Waste. Safety Requirements. Rules and Regulations NP-019-2015]. Moscow: Gosatomnadzor of Russia, 2015. 22 p. Russian. 